\title{
MODEL PEMBELAJARAN PROJECT BASED LEARNING - AUDIT KEPATUHAN
}

\author{
Irsutami $^{1)}$, Danar Irianto ${ }^{2}$, Muhammad Ikhlash ${ }^{3}$, Sugeng Riadi ${ }^{4}$ \\ $1,2,3,4)$ Jurusan Manajemen Bisnis, Politeknik Negeri Batam \\ 1e-mail: tami@polibatam.ac.id, 2e-mail: danar@polibatam.ac.id 3e-mail: ikhlash@polibatam.ac.id, 4 e- \\ mail: sugeng@polibatam.ac.id
}

\begin{abstract}
This researsh relatating with the compliance audit in the auditing course. In way with industry 4.0 and independent learning, this learning material is very appropriate when using Project Based Learning (PBL), where students will visit companies or agencies to see the level of employee / employee compliance with the established regulations. The involvement of several parties (auditee) inside and or outside the campus is the background for this research proposal with the aim of obtaining a learning model through project-based learning for compliance audit material. The results of the study will be useful for lecturers who apply the PBL method for compliance audit. The methodology used is interviews with academics and audit practitioners or auditors from BPKP, BPK RI, and Higher Education Internal Supervisory Units where interviews are conducted through questionnaires that are distributed directly, another method is literature study. The research design was a survey with an interactive method of analysis. The results of this study are a learning model with the PBL method which can be a reference for teachers of the Auditing course.
\end{abstract}

Keywords: Learning Model, Project Based Learning, Compliance Audit

\begin{abstract}
ABSTRAK
Penelitian ini berkaitan dengan materi audit kepatuhan pada mata kuliah auditing. Sejalan dengan industry 4.0 dan merdeka belajar, maka pembelajaran materi ini sangat tepat jika menggunakan Project Based Learning $(P B L)$, di mana mahasiswa akan berkunjung ke perusahaan atau instansi untuk melihat tingkat kepatuhan karyawan/pegawai terhadap peraturan yang ditetapkan. Adanya keterlibatan beberapa pihak (auditee) di dalam dan atau di luar kampus adalah hal yang melatarbelakangi diajukannya penelitian ini dengan tujuan untuk mendapatkan suatu model pembelajaran melalui project-based learning untuk materi audit kepatuhan. Hasil penelitian akan berguna bagi dosen yang menerapkan metode PBL untuk materi audit kepatuhan. Metodologi yang digunakan adalah wawancara kepada akademisi dan praktisi audit atau auditor yang berasal dari BPKP, BPK RI, dan Satuan Pengawasan Internal Perguruan Tinggi di mana wawancara dilakukan melalui kuisioner yang dibagikan secara langsung, metode lainnya adalah studi pustaka. Desain penelitian adalah survei dengan metode analisis adalah interaktif. Adapun hasil dari penelitian ini adalah suatu model pembelajaran dengan metode PBL yang dapat menjadi referensi para pengajar mata kuliah Auditing.
\end{abstract}

Kata Kunci: Model Pembelajaran, Project Based Learning, Audit Kepatuhan 


\section{PENDAHULUAN}

Persaingan bebas yang terjadi di era globalisasi menuntut individu untuk membekali diri dengan keahlian dan wawasan yang luas. Salah satu bentuk persaingan bebas yang terjadi saat ini adalah adanya persetujuan pasar bebas Masyarakat Ekonomi ASEAN (MEA) tahun 2015. Masyarakat Ekonomi ASEAN akan menjadi peluang dan tantangan bagi masyarakat Indonesia untuk dapat bersaing dengan negara-negara ASEAN. Program dari salah satu persetujuan MEA adalah free flow labor service (arus bebas jasa tenaga kerja) termasuk di dalamnya adalah jasa akuntan. Bagaimana cara mempersiapkan akuntan-akuntan Indonesia untuk dapat bersaing dengan akuntan dari negara lain? Langkah awal untuk menyiapkan akuntan Indonesia agar dapat bersaing dengan akuntan negara lain adalah meningkatkan kualitas pendidikan bagi para calon akuntan dalam hal ini adalah mahasiswa akuntansi.

Salah satu ilmu yang diberikan oleh perguruan tinggi kepada mahasiswa akuntansi adalah mata kuliah auditing. Auditing atau pemeriksaan merupakan mata kuliah yang diajarkan di hampir semua perguruan tinggi negeri dan swasta. pada fakultas/jurusan ekonomi di universitas, politeknik, maupun sekolah tinggi untuk berbagai jenjang pendidikan. Pembelajaran mata kuliah ini rata-rata menitikberatkan pada pemeriksaan atas laporan keuangan untuk sektor privat atau swasta dengan capaian pembelajaran yang berbeda-beda. Bagi pendidikan strata satu (S-1) dan pendidikan diploma empat (D4), capaian pembelajaran mata kuliah ini mengharapkan mahasiswa agar mampu merancang audit atas laporan keuangan yang terdiri dari perencanaan audit, pelaksanaan audit, dan pelaporan hasil auditnya, sedangkan untuk pendidikan diploma tiga (D-3) lebih menekankan pada pemahaman proses pengauditan atas laporan keuangan.
Cara meningkatkan kualitas pembelajaran pada perguruan tinggi dan menyiapkan lulusan mahasiswa yang terampil dan siap kerja dibutuhkan metode yang tepat. Menurut UNESCO dalam (Herawan \& Rahayu, 2016), pendidikan memiliki dua basis landasan, yang pertama pendidikan harus diletakkan pada empat pilar yaitu belajar mengetahui (learning to know), belajar melakukan (learning to do), belajar hidup dalam kebersamaan (learning to live together), dan belajar menjadi diri sendiri (learning to be); kedua, belajar seumur hidup (life-long learning). Sedangkan menurut (Ace \& Rahmat, 2016), ada beberapa model pembelajaran sebagai pedoman untuk para pengajar salah satunya adalah metode project-based learning (PBL). Projectbased learning merupakan model pembelajaran yang berasal dari gagasan John Dewey tentang konsep "learning by doing" yaitu proses perolehan hasil belajar dengan mengerjakan tindakan tindakan tertentu sesuai dengan tujuan. Model ini dapat digunakan sebagai sebuah model pembelajaran untuk mengembangkan kemampuan peserta didik dalam membuat perencanaan, berkomunikasi, menyelesaikan masalah dan membuat keputusan yang tepat dari masalah yang dihadapi (Nurfitriyanti, 2016)

Hasil penelitian (Gangga, 2013) menyatakan bahwa penerapan project based learning dalam proses belajar mengajar menjadi sangat penting untuk meningkatkan kemampuan peserta didik dalam berfikir kritis dan memberi rasa kemandirian dalam belajar. Hasil penelitian lainnya menurut (Mukhayyaroh \& Arief, 2018), bahwa penerapan model PBL lebih efektif dalam meningkatkan kreativitas mahasiswa, motivasi belajar dan hasil belajar. Berdasarkan latar belakang di atas maka saatnya perguruan tinggi harus mengubah metode pembelajaran yang kuno, di mana mahasiswa hanya mendengarkan (pasif) sedangkan pengajar hanya menerangkan 
saja (aktif). Metode PBL salah satu metode yang perlu diterapkan khususnya mata kuliah auditing. Perlu sebuah model pembelajaran sebagai pedoman pengajar untuk mata kuliah audit (khusus audit kepatuhan). Oleh karena itu, penulis akan meneliti mengenai "Model Pembelajaran Project Based Learning-Audit Kepatuhan".

Adapun tujuan dari penelitian ini adalah untuk mendapatkan suatu model pembelajaran melalui project-based learning untuk materi kuliah audit kepatuhan pada mata kuliah auditing.

\section{KAJIAN LITERATUR}

\subsection{Pengertian Auditing}

Audit menurut (Arens, Elder, \& Beasley, 2015) adalah accumulation and evaluation of evidence about information to determine and report on the degree of correspondence between the information and established criteria. Auditing should be done by a competent, independent person. Sedangkan menurut (Agoes, Auditing: Petunjuk Praktis Pemeriksaan Akuntan oleh Akuntan Publik, 2012), audit merupakan suatu pemeriksaan yang dilakukan secara kritis dan sistematis, oleh pihak yang independen, terhadap laporan keuangan yang telah disusun oleh manajemen, beserta catatan-catatan pembukuan dan bukti-bukti pendukungnya, dengan tujuan untuk dapat memberikan pendapat mengenai kewajaran laporan keuangan.

\subsection{Pengertian Audit Kepatuhan}

Menurut (Mulyadi, 2014), audit kepatuhan adalah audit yang tujuannya untuk menentukan apakah yang diaudit sesuai dengan kondisi atau peraturan tertentu. Hasil audit kepatuhan umumnya dilaporkan kepada pihak yang berwenang membuat kriteria. Audit kepatuhan banyak dijumpai dalam pemerintahan.

Menurut (Agoes, 2017), audit kepatuhan adalah pemeriksaan yang dilakukan untuk mengetahui apakah perusahaan sudah mentaati peraturan- peraturan dan kebijakan-kebijakan yang berlaku, baik yang ditetapkan oleh pihak internal perusahaan (manajemen, dewan komisaris) maupun pihak eksternal (pemerintah, BAPEPAM LK, Bank Indonesia, Direktorat Jenderal Pajak, dan lain-lain).

\subsection{Tujuan Audit Kepatuhan}

Menurut (Arens, Elder, \& Beasley, 2015), tujuan audit kepatuhan adalah untuk menentukan apakah pihak yang diaudit telah mengikuti prosedur, kebijakan, dan regulasi yang telah ditetapkan oleh badan/otoritas yang lebih tinggi. Hasil dari audit kepatuhan biasanya berupa pernyataan temuan atau tingkat kepatuhan dan dilaporkan kepada pihak tertentu dalam unit organisasi yang diaudit.

Menurut Ikatan Akuntan Indonesia (IAI), audit kepatuhan berkaitan dengan kegiatan memperoleh dan memeriksa bukti-bukti untuk menetapkan apakah kegiatan keuangan atau operasi suatu entitas telah sesuai dengan persyaratan ketentuan, atau peraturan tertentu. Audit kepatuhan berfungsi untuk menentukan sejauh mana peraturan, kebijakan, hukum, perjanjian, atau peraturan pemerintah dipatuhi oleh entitas yang sedang diaudit.

\subsection{Manfaat dan Pentingnya Audit Kepatuhan \\ Menurut (Agoes, 2012), audit} kepatuhan harus dilakukan di dalam perusahaan terhadap:

a. Kebijakan dan prosedur tertulis tentang kelengkapan transaksi

Hal ini dilakukan untuk membuktikan adanya kepatuhan terhadap kelengkapan transaksi yang dilakukan dalam perusahaan, pelaksanaan transaksi tersebut sejak transaksi dimulai sampai dengan selesai.

b. Kepatuhan terhadap perundangundangan

Dalam setiap aspek operasional perusahaan atau bagian organisasi perusahaan harus memenuhi setiap 
peraturan perundang-undangan dan peraturan internal perusahaan.

\subsection{Langkah-Langkah Audit Kepatuhan}

Langkah-langkah dalam melakukan audit kepatuhan adalah sebagai berikut:
a. Tahap pertimbangan awal
b. Tahap perencanaan audit
c. Tahap pelaksanaan audit dan pengumpulan bukti
d. Tahap evaluasi bukti dan perumusan simpulan
e. Tahap pelaporan

\subsection{Output Audit Kepatuhan}

(Arens, Elder, \& Beasley, 2015) menjelaskan bahwa hasil audit kepatuhan berbeda dengan hasil audit laporan keuangan yang harus dilaporkan ke pengguna, hasil audit kepatuhan hanya dilaporkan ke manajemen perusahaan saja, karena manajemen adalah pihak yang berkepentingan melihat kepatuhan perusahaan atas prosedur dan regulasi yang ditetapkan.

\subsection{Model Pembelajaran Project-Based Learning}

Menurut (Afriana, 2015), pembelajaran berbasis proyek (project-based learning) merupakan model pembelajaran yang berpusat pada peserta didik dan memberikan pengalaman belajar yang bermakna bagi peserta didik. Pengalaman belajar peserta didik maupun konsep dibangun berdasarkan produk yang dihasilkan dalam proses pembelajaran berbasis proyek.

$\begin{array}{llr}\text { Pembelajaran berbasis } & \text { proyek } \\ \text { merupakan model belajar } & \text { yang } \\ \text { menggunakan masalah sebagai langkah } & \text { lan } \\ \text { awal dalam mengumpulkan } & \text { dan } \\ \text { mengintegrasikan pengetahuan } & \text { baru }\end{array}$
berdasarkan pengalamannya dalam berkreativitas secara nyata. Pembelajaran berbasis proyek dirancang untuk digunakan pada permasalah komplek yang diperlukan peserta didik dalam melakukan investigasi dan memahaminya (Hamdayama, 2015).
Menurut (Trianto, 2011), model pembelajaran berbasis proyek memiliki potensi yang amat besar untuk membuat pengalaman belajar yang lebih menarik dan bermanfaat bagi peserta didik (Santyasa, 2006). Dalam pembelajaran berbasis proyek, peserta didik terdorong lebih aktif dalam belajar. Dosen hanya sebagai fasilitator, mengevaluasi produk hasil kerja peserta didik yang ditampikan dalam hasil proyek yang dikerjakan, sehingga menghasilkan produk nyata yang dapat mendorong kreativitas mahasiswa agar mampu berpikir kritis dalam menganalisa faktor dalam konsep masalah dalam perkuliahan.

\subsection{Manfaat Model Pembelajaran PBL}

Menurut (Moursund, 2003), pembelajaran berbasis proyek memiliki beberapa keuntungan antara lain:

a. Increased motivation

b. Increased problem-solving ability

c. Increased library research skills

d. Increased collaboration

e. Increased resource-management skills

\section{METODE PENELITIAN}

Penelitian ini menggunakan pendekatan deskriptif kualitatif. Penelitian deskriptif kualitatif ditujukan untuk mendeskripsikan dan menggambarkan fenomena-fenomena yang ada (Sukmadinata, Metode Penelitian Pendidikan, 2011).

Penelitian tersebut menggunakan studi kasus karena peneliti ingin menggali lebih dalam informasi yang berkaitan dengan kondisi saat ini mengenai minat mahasiswa/mahasiswi. Informasi tersebut dapat membantu peneliti mendapatkan solusi mengenai sebuah model pembelajaran sebagai pedoman pengajar untuk mata kuliah audit (khususnya audit kepatuhan).

Sumber data yang diperlukan dalam penelitian ini adalah yang diperoleh melalui wawancara terstruktur, observasi partisipan (participant as observer), inspeksi dokumen dan dokumentasi. 
Pengumpulan data yang dilakukan dalam penelitian ini menggunakan teknik wawancara mendalam (in depth interview) dan dokumentasi. Wawancara akan dilakukan kepada praktisi dan akademisi. Materi wawancara ke akademisi akan diarahkan pada permintaan pendapat dan ide-ide terkait audit kepatuhan dan model pembelajaran audit kepatuhan melalui project based learning, sedangkan wawancara ke praktisi dari kantor akuntan publik akan diarahkan pada pentingnya audit kepatuhan dan pelaksanaan praktik audit kepatuhan yang biasa dilakukan oleh KAP.

Teknik analisis yang digunakan dalam penelitian tersebut adalah teknik analisis data interaktif. Teknik tersebut terdiri atas empat tahap kegiatan yaitu pengumpulan data, reduksi, penyajian dan penarikan kesimpulan dari data. Data yang dikumpulkan dari hasil wawancara dipetakan dan kemudian dianalisis untuk menjawab pertanyaan penelitian.

\section{PEMB AHASAN}

\subsection{Persiapan Audit Kepatuhan}

Responden dalam penelitian ini terdiri dari para praktisi dan akademisi. Praktisi dipilih dari instansi pemerintah seperti BPK dan BPKP yang memiliki pengalaman dalam bidang audit dengan pendidikan minimal sarjana dan menduduki jabatan sebagai auditor dan ketua satuan pengawasan internal dan ratarata memiliki pengalaman di atas 5 tahun. Akademisi dalam penelitian ini memiliki tingkat pendidikan minimal magister yang memiliki pengalaman mengajar auditing di atas 5 tahun.

\subsubsection{Desain Proyek Audit}

a. Tahap Pra Audit

Adapun kegiatan yang harus dilakukan oleh auditor atau tim audit pada tahap pra audit adalah:

1) Menentukan Tujuan Audit

2) Menentukan Ruang Lingkup Audit

3) Menentukan Tim dan Jadwal Audit termasuk Person in Charge (PIC)
4) Menentukan Pendekatan atau Metode Audit yang Akan Digunakan

5) Menentukan Objek Audit dan Identifikasi Masalah

6) Menentukan Lokasi dan Area Audit

7) Menentukan Alat dan Bahan yang Akan Digunakan

8) Norma audit (Hal yang boleh dan tidak boleh dilakukan saat audit)

b. Tahap Pelaksanaan Audit Kepatuhan

Adapun kegiatan yang harus dilakukan oleh auditor atau tim audit pada tahap pelaksanaan adalah:

1) Pengumpulan bukti audit

2) Memutakhirkan perencanaan dan penilaian risiko

3) Dokumentasi

4) Komunikasi

5) Pengendalian kualitas secara terusmenerus

6) Mempertimbangkan non-kepatuhan yang mungkin mengindikasikan adanya dugaan tindakan melawan hukum.

c. Tahap Evaluasi Bukti Audit

Kepatuhan

Adapun kegiatan yang harus dilakukan oleh auditor atau tim audit pada tahap evaluasi adalah:

1) Evaluasi apakah bukti yang sesuai dan cukup telah diperoleh

2) Mempertimbangkan materialitas untuk keperluan pelaporan

3) Merumuskan simpulan

4) Memperoleh surat representasi tertulis jika diperlukan

5) Membahas kejadian setelah tanggal pelaporan jika diperlukan.

d. Tahap Pelaporan Audit Kepatuhan

Adapun kegiatan yang harus dilakukan oleh auditor atau tim audit pada tahap pelaporan adalah:

1) Penyiapan laporan

2) Memasukkan rekomendasi dan tangapan dari entitas secara tepat

3) Menindaklanjuti laporan sebelumnya jika ada. 


\subsubsection{Pelaporan Hasil Audit Kepatuhan oleh Tim Audit}

Tahap pelaporan audit kepatuhan berbeda dengan pelaporan hasil audit kepatuhan. Pada tahap pelaporan audit kepatuhan, tim audit akan menyusun laporan terkait dengan temuan yang didapatkan selama masa penugasan di mana dari temuan tersebut selanjutnya akan menjadi dasar dalam memberikan rekomendasi kepada auditee. Pelaporan ini dibuat oleh tim audit sebagai perwujudan tanggung jawabnya terhadap penugasan yang diberikan. Sedangkan pelaporan hasil audit kepatuhan lebih kepada pelaporan hasil audit secara keseluruhan termasuk didalamnya konerja dari tim audit. Pelaporan ini selanjutkan akan dipresentasikan ke dosen dan pembimbing tim audit.

\subsubsection{Evaluasi Pelaksanaan Audit Kepatuhan}

Evaluasi terhadap hasil audit kepatuhan terdiri dari 2 (dua) bagian yaitu evaluasi terhadap kinerja proses audit kepatuhan kepada masing-masing tim audit dan evaluasi terhadap kinerja hasil audit kepatuhan yang dihasilkan oleh tim audit. Evaluasi yang pertama didasarkan pada lembar pemantauan atau logbook yang terdiri dari pemantauan terhadap tahap persiapan tim, tahap pelaksanaan, dan tahap pelaporan. Hasil evaluasi ini menjadi dasar bagi dosen untuk memberikan nilai bagi mahasiswa.

\subsection{Pra Audit Kepatuhan}

\subsubsection{Menentukan Tujuan Audit}

Tujuan ini perlu dipahami oleh mahasiswa atau tim audit sebagai hasil akhir yang akan dituju, sehingga tim audit dapat mengetahui tingkat kepatuhan pegawai terhadap peraturan atau kebijakan yang memang harus dipatuhi. Dalam merumuskan tujuan audit perlu dipertimbangkan dukungan sumber daya yang ada antara lain; biaya yang dibutuhkan, sumber daya manusia atau auditor yang dibutuhkan, dan waktu yang tersedia untuk melaksanaan audit yang disesuaikan dengan batas akhir perkuliahan di masing-masing perguruan tinggi. Pertimbangan biaya yang dibutuhkan ini sangat penting mengingat bahwa kegiatan PBL ini dilakukan di luar kelas atau biasa secara online yang membutuhkan biaya komunikasi secara online. Selain itu, kegiatan ini dilakukan sepenuhnya oleh mahasiswa yang diharapkan tidak menimbulkan biaya tambahan dalam penyelesaian proyeknya karena uang kuliah yang dibayarkan sudah termasuk fasilitas yang harus diperoleh mahasiswa. Pertimbangan jumlah mahasiswa juga perlu dipertimbangkan karena jika mahasiswa yang terlibat dalam suatu tim cukup banyak, maka proses pelaksanaannya bisa berjalan tidak efektif sehingga terkendala dalam mencapai tujuan audit yang telah ditetapkan. Demikian halnya masalah waktu yang perlu dipertimbangkan mengingat PBL ini dilakukan di pertengahan semester dan berhubungan dengan pihak lain atau bisa saja berhubungan dengan pihak luar kampus seperti perusahaan atau instansi pemerintah.

\subsubsection{Menentukan Ruang Lingkup Audit Kepatuhan}

Adapun langkah-langkah dalam penentuan lingkup audit adalah:

a. Tentukan lingkup audit atas dasar informasi yang diperoleh pada dokumentasi PBL audit kepatuhan semester sebelumnya atau berdasarkan hasil pembicaraan dengan auditee. Auditee yang berada di luar kampus (perusahaan atau instansi pemerintah) terkadang membatasi ruang lingkup yang akan dijadikan objek audit. Untuk itu, dalam praktiknya, sebaiknya mengikuti arahan dari auditee selama tujuan yang telah ditetapkan bisa tercapai. Peranan dari dosen pengajar sangat dibutuhkan dalam penentuan ruang lingkup audit namun tetap mengikutertakan mahasiswa atau tim audit dalam pengambilan keputusannya. 
b. Lakukan perubahan dalam lingkup audit apabila informasi yang diperoleh dalam pelaksanaan audit mengharuskan demikian. Perubahan lingkup audit bisa saja mengalami perubahan dalam pelaksanaan audit apabila proses wawancara atau inspeksi dokumen mengalami hambatan atau terdapat perubahan manajemen atau pimpinan dari organisasi auditee.

4.2.3. Menentukan Tim dan Jadwal Audit

Audit yang dilakukan seminimal mungkin tidak mengganggu pekerjaan pihak yang diaudit. Untuk itu, jadwal audit harus disusun untuk dapat disepakati antara pihak tim audit dan auditee. Jadwal pelaksanaan audit ini sangat penting mengingat adanya keterbatasan waktu dalam pelaksanaan audit. Selain itu, jadwal yang telah disusun dan disepakati ini merupakan bentuk komitmen terlaksananya audit secara lancar.

\subsubsection{Menentukan Pendekatan atau}

Metode Audit yang Akan Digunakan

Mengingat alternatif pendekatan atau metode audit yang tersedia, maka auditor dan auditee harus memutuskan untuk menggunakan pendekatan yang paling sesuai. Pendekatan atau metode audit yang dipilih hendaknya juga memperhatikan dukungan sumber daya yang ada. Misalnya inspeksi dokumen (walktrought) yang relatif akan menghabiskan waktu yang lama sehingga kurang sesuai untuk jangka waktu audit yang sangat singkat. Demikian juga SDM atau jumlah auditor yang akan melakukan audit harus menjadi salah satu pertimbangan dalam memilih pendekatan audit

4.2.5. Menentukan Objek Audit dan Identifikasi Masalah

Objek audit kepatuhan yang dimaksud di sini adalah lokasi tempat dilakukannya audit kepatuhan. Adapun jenis objek audit kepatuhan terdiri dari:

a. Unit kerja dari perusahaan atau lembaga atau instansi pemerintah dan non pemerintah atau unit-unit kerja di dalam lingkungan perguruan tinggi, misalnya program studi, jurusan atau fakultas, unit pelaksana teknis (UPT), bagian atau unit terkecil.

b. Perusahaan (jasa, perdagangan, dan manufaktur)

c. Lembaga atau instansi pemerintah 4.2.6. Menentukan Pembimbing Tim Audit

Dosen perlu menentukan pembimbing tim audit yang bertindak sebagai senior auditor (project manager). Kualifikasi dari calon pembimbing tim audit adalah mahasiswa yang pernah mendapatkan materi project-based learning audit kepatuhan dan telah menyelesaikan mata kuliah auditing serta direkomendasikan oleh dosen pengajar dengan persetujuan dosen pengampu. Jumlah pembimbing disesuaikan dengan jumlah tim audit yang dibentuk.

4.2.7. Menghubungi atau Mengunjungi Objek Audit Kepatuhan

Objek audit kepatuhan bisa dihubungi melalui email atau menyurat secara langsung, namun sebaiknya dosen atau mahasiswa melakukan kunjungan langsung untuk membicarakan maksud dari PBL yang akan dilakukan. Di dalam redaksi atau pembicaraan dengan pihak auditee harus diputuskan kebijakan apa yang akan menjadi dasar untuk menentukan tingkat kepatuhan karyawan. Ada berbagai kebijakan yang bisa menjadi dasar yaitu:

a. Peraturan unit kerja atau perusahaan atau instansi pemerintah dan non pemerintah.

b. Standart Operational Procedure (SOP) unit kerja atau perusahaan atau instansi pemerintah atau non pemerintah.

c. Instruksi kerja, baik berupa instruksi kerja mesin atau peralatan lainnya.

\subsubsection{Membentuk Tim Audit}

Tim Audit dibentuk oleh dosen dengan mengelompokkan beberapa mahasiswa. Menurut (Hare, 1962), jumlah orang dalam satu kelompok yang ideal adalah $7-10$ orang, sedangkan jumlah minimal adalah 2 - 3 orang. Namun demikian, banyaknya jumlah orang dalam satu kelompok 
disesuaikan dengan jumlah tugas yang akan dilakukan oleh tim tersebut dan jumlah mahasiswa dalam satu kelas. (Sharan \& Sharan, 1992) menyatakan bahwa komposisi kelompok diupayakan heterogen, baik dalam jenis kelamin, etnik, maupun kemampuan akademik. Dosen boleh menggunakan kedua kombinasi tersebut di atas. Setiap kelompok tim audit yang dibentuk dipimpin oleh 1 (satu) orang ketua yang bertugas mengarahkan anggotanya serta membagi tugas yang akan dilakukan. Penentuan ketua tim audit didasarkan pada hasil pre-test yang dilakukan oleh dosen.

\subsubsection{Menyiapkan Peralatan,}

Perlengkapan, dan Dokumen Audit Kepatuhan

Dokumen yang perlu disiapkan dalam rangka pelaksanaan audit kepatuhan adalah sebagai berikut:

a. Kebijakan yang menjadi acuan untuk mengukur tingkat kepatuhan karyawan.

b. Daftar pertanyaan atau internal control quistionaire. Daftar pertanyaan ini mengacu pada kebijakan yang menjadi dasar. Untuk program Diploma 3 (tiga), daftar pertanyaan ini akan dibuat oleh dosen, sedangkan untuk program Diploma 4 (empat), daftar pertanyaan harus dirancang oleh kelompok tim audit masing-masing. Daftar pertanyaan ini merupakan kertas kerja audit yang dihasilkan setelah tim audit melakukan wawancara.

\subsection{Pelaksanaan Audit Kepatuhan}

Pelaksanaan audit kepatuhan ini dilakukan dalam 2 (dua) tahap yakni tahap wawancara dan tahap pengujian. Pada tahap wawancara, tim audit akan melakukan wawancara langsung kepada auditee berdasarkan daftar pertanyaan atau kuisioner. Proses pembuatan daftar pertanyaan atau kuisioner oleh tim audit dibawah arahan pembimbing untuk mahasiswa program Diploma IV, sedangkan untuk mahasiswa program Diploma III, maka daftar pertanyaan sepenuhnya dibuat oleh dosen pengajar.

4.3.1. Pengisian Daftar Pertanyaan (Kunjungan Pertama)

4.3.1.1. Briefing oleh Dosen Sebelum Wawancara

Briefing dilakukan oleh dosen pengajar dengan materi berupa mekanisme atau teknis wawancara kepada auditee. Hal ini sangat penting karena secara teknis, wawancara dengan auditee dalam rangka pengisian daftar pertanyaan, berbeda dengan pengisian daftar pertanyaan pada umumnya seperti kuisioner.

\subsubsection{Pembagian Tugas Anggota Tim oleh Ketua Tim}

Adapun tugas yang akan dibagi adalah anggota yang meyiapkan peralatan dan perlengkapan wawancara, anggota yang menghubungi pihak auditee, anggota yang melakukan tanya jawab atau wawancara (pertimbangkan jika wawancara dilakukan ke lebih dari 1 (satu) auditee, anggota yang mencatat hasil wawancara, anggota yang me-review hasil wawancara, dan anggota yang melakukan pengambilan gambar atau foto.

\subsubsection{Wawancara Langsung ke Auditee oleh Tim Audit}

Wawancara dilakukan sesuai dengan jadwal yang disepakati dengan auditee. Wawancara bisa saja dilakukan ke lebih dari 1 (satu) auditee. Wawancara dilakukan dengan bertatapan langsung atau menggunakan media online jika disetujui oleh auditee.

\subsubsection{Review Hasil Wawancara oleh Pembimbing}

Pembimbing harus melakukan review terhadap daftar pertanyaan yang telah terisi sebelum tim melakukan tabulasi, bukti bahwa dosen telah melakukan review berupa pembubuhan tanda tangan pada lembar daftar pertanyaan. Jika pembimbing ada keraguan, konsultasi ke dosen pengajar.

4.3.1.5. Tabulasi Hasil Wawancara 
Daftar pertanyaan yang sudah terisi dan sudah ditandatangani oleh pembimbing, selanjutnya akan ditabulasi oleh tim audit.

\subsubsection{Review Hasil Tabulasi oleh} Pembimbing

Pembimbing harus melakukan review terhadap kertas kerja hasil tabulasi, bukti bahwa pembimbing telah melakukan review berupa pembubuhan tanda tangan pada kertas kerja. Jika pembimbing ada keraguan, konsultasi ke dosen pengajar.

\subsubsection{Penyusunan Kertas Kerja Kesimpulan Sementara Tingkat Kepatuhan Auditee}

Kertas kerja hasil tabulasi bisa saja lebih dari 1 (satu), maka dari itu, tim harus melakukan penyusunan kertas kerja tersebut agar mudah dibaca.

\subsubsection{Review Kertas Kerja oleh Pembimbing}

Pembimbing harus melakukan review terhadap kertas kerja yang telah disusun oleh tim, bukti bahwa pembimbing telah melakukan review berupa pembubuhan tanda tangan pada kertas kerja. Jika pembimbing ada keraguan, konsultasi ke dosen pengajar.

4.3.1.9. Evaluasi Bukti dan Penarikan Kesimpulan Sementara Tingkat Kepatuhan Auditee oleh Tim Audit

Kesimpulan didasarkan pada hasil tabulasi dengan kategori sebagai berikut:

Tabel 1. Dasar Kesimpulan Hasil Tabulasi

\begin{tabular}{|c|c|}
\hline SKALA & KESIMPULAN \\
\hline $0 \%-25 \%$ & Sangat Buruk \\
\hline $26 \%-50 \%$ & Cukup Baik \\
\hline $51 \%-75 \%$ & Baik \\
\hline $76 \%-100 \%$ & Sangat Baik \\
\hline
\end{tabular}

4.3.2. Pengujian Hasil Jawaban Auditee (Kunjungan Kedua)

\subsubsection{Briefing oleh Dosen Sebelum Inspeksi Dokumen}

Briefing dilakukan oleh dosen pengajar dengan materi berupa mekanisme atau teknis pengujian yang akan dilakukan oleh tim.

\subsubsection{Pembagian Tugas Auditor oleh Ketua Tim}

Adapun tugas yang akan dibagi adalah anggota yang menyiapkan peralatan dan perlengkapan inspeksi dukumen, anggota yang menghubungi pihak auditee, anggota yang melakukan permintaan dokumen (pertimbangkan jika wawancara dilakukan ke lebih dari 1 (satu) auditee), anggota yang memeriksa dokumen, anggota yang mencatat hasil pemeriksaan dokumen, dan anggota yang melakukan pengambilan gambar atau foto.

\subsubsection{Inspeksi Dokumen (Walktroght)} \& Pembuktian

Pada dasarnya, inspeksi dokumen \& pembuktian ini dilakukan dalam rangka membuktikan jawaban Ya yang diberikan oleh auditee di mana telah dijelaskan sebelumnya bahwa pembuktian dapat dilakukan dengan melihat atau mengecek dokumen maupun observasi atau pengamatan. Pembuktian dapat berupa bukti fisik, bukti dokumen, bukti matematis atau hal lainnya yang bersifat membuktikan sesuai dengan yang terdapat pada daftar pertanyaan.

4.3.2.4. Review Hasil Inspeksi Dokumen oleh Dosen

Hasil inspeksi dokumen dan pembuktian dalam bentuk draf selanjutnya akan di-review oleh dosen untuk keperluan pembuatan kertas kerja.

4.3.2.5. Penyusunan Kertas Kerja Hasil Inspeksi Dokumen dan Pembuktian

Seluruh hasil inspeksi dokumen dan pembuktian selanjutnya dirangkum dalam suatu kertas kerja.

\subsubsection{Review Kertas Kerja oleh Dosen}

Semua kertas kerja yang dihasilkan dalam pelaksanaan inspeksi dokumen dan pembuktian selanjutnya akan di-review oleh dosen.

4.3.2.7. Evaluasi Bukti dan Perumusan Simpulan Penarikan Kesimpulan Akhir Tingkat Kepatuhan Auditee dan Perumusan Rekomendasi oleh Tim Audit 
Kesimpulan akhir terhadap tingkat kepatuhan karyawan didasarkan pada hasil pengujian atau pembuktian. Jika terdapat perbedaan antara hasil wawancara dan pengujian, maka yang diambil adalah hasil pengujian karena hasil pengujian didasarkan pada adanya bukti berupa dokumen dan hasil pengamatan. Jika semua jawaban Ya dapat dibuktikan, maka dipastikan tingkat kepatuhan karyawan terhadap kebijakan yang diberlakukan oleh perusahaan adalah sangat baik dan demikian sebaliknya. Adapun bentuk rekomendasi yang akan diberikan oleh tim audit mengarah pada peningkatan efektivitas pemberlakukan kebijakan yang ada dan edukasi terhadap karyawan.

\subsection{Pelaporan Hasil Audit Kepatuhan oleh Tim Audit}

4.4.1. Pelaporan Hasil Audit Kepatuhan

Pelaporan hasil audit ini dilakukan oleh tim audit dalam bentuk video presentasi yang selanjutnya menjadi dasar bagi dosen pengajar untuk memberikan penilaian terkait materi audit kepatuhan yang ditugaskan. Adapun hal-hal yang perlu menjadi perhatian agar tahap pelaporan hasil audit kepatuhan ini dapat disajikan dengan baik oleh tim audit adalah sebagai berikut:

\subsubsection{Briefing oleh Dosen}

Dosen memberikan briefing atau pengarahan kepada semua tim audit. Adapun materi pengarahan yang harus disampaikan kepada tim audit adalah pembagian tugas oleh ketua tim, penyusunan bundel pelaporan audit, pembuatan slide presentasi, pembuatan video, dan presentasi hasil audit kepatuhan.

4.4.1.2. Pembagian Tugas Auditor oleh Ketua Tim

Adapun tugas-tugas yang harus dibagikan ke semua anggota tim audit adalah pembuatan slide presentasi, pembuatan video presentasi, presentasi kertas kerja oleh masing-masing anggota tim audit, dan penyusunan pelaporan hasil audit kepatuhan.

\subsubsection{Penyusunan Bundel Kertas Kerja, Dokumen, dan Foto Hasil Audit Kepatuhan}

Penyusunan bundel kertas kerja ini sangat penting karena kertas kerja yang dihasilkan lebih dari 1 (satu) dan masingmasing kertas kerja saling terkait, untuk itu diperlukan penyusunan yang nantinya akan mempermudah dosen dalam melakukan pemeriksaan.

4.4.1.4. Pembuatan Slide Presentasi Hasil Audit Kepatuhan

Pembuatan slide presentasi menggunakan power point di mana seluruh dokumen, kertas kerja, dan foto-foto saat melakukan wawancara dan pengujian hasil jawaban auditee wajib ditampilkan dalam slide presentasi.

4.4.1.5. Review Slide Presentasi oleh Dosen

Draf slide presentasi selanjutnya direview oleh dosen pengajar agar pola penyajian slide presentasi masing-masing tim memenuhi standar presentasi yang sudah ditentukan oleh dosen.

4.4.1.6. Pembuatan Video Presentasi Hasil Audit Kepatuhan

Berdasarkan slide presentasi yang sudah disetujui oleh dosen, maka selanjutnya masing-masing tim akan membuat video presentasi. Di dalam video presentasi, semua anggota tim akan mendapatkan tugas sesuai dengan yang telah dibagikan oleh ketua tim. Dalam pembuatan video presentasi, mahasiswa diwajibkan menggunakan pakaian resmi perkantoran, untuk laki-laki menggunakan celana panjang, baju lengan panjang dan dasi sedangkan perempuan menggunakan celana panjang atau rok dan baju kemeja serta blazer. Semua tim audit sebaiknya berdandan agar tampilan di video lebih elegan.

\subsubsection{Review Video Presentasi oleh} Dosen

Draf video presentasi kemudian direview oleh dosen agar supaya memenuhi standar presentasi yang baik. Dosen perlu menetapkan durasi presentasi yang berlaku untuk semua kelompok dan juga 
menentukan hal-hal apa saja yang perlu dipresentasikan.

\subsubsection{Pelaporan}

Pelaporan hasil audit kepatuhan terdiri:

a. Bundel pelaporan hasil audit kepatuhan yang didalamnya terdapat hasil wawacara dan hasil pengujian hasil jawaban auditee (dokumen, kertas kerja, dan foto-foto). Adapun format bundel pelaporan hasil audit kepatuhan adalah sebagai berikut:

b. Video presentasi. Pelaporan hasil audit tersebut di atas kemudian diunggah (upload) ke google drive oleh masing-masing tim dan kemudian link-nya dikirim ke dosen pengajar untuk dilakukan penilaian.

\subsubsection{Menyampaikan Laporan ke Auditee}

Sebagai bentuk tanggung jawab atas penugasan yang telah dilakukan, maka seluruh hasil audit kepatuhan ini akan disampaikan kepada auditee untuk menindaklanjuti rekomendasi yang diberikan oleh tim audit.

\subsection{Evaluasi Hasil Audit Kepatuhan}

Evaluasi terhadap hasil audit kepatuhan terdiri dari 2 (dua) bagian yaitu evaluasi terhadap kinerja proses audit kepatuhan kepada masing-masing tim audit dan evaluasi terhadap kinerja hasil audit kepatuhan yang dihasilkan oleh tim audit. Evaluasi yang pertama didasarkan pada lembar pemantauan atau logbook yang terdiri dari pemantauan terhadap tahap persiapan tim, tahap pelaksanaan, dan tahap pelaporan. Format lembar pemantauan masing-masing tahap tersebut dibuat oleh dosen, sedangkan yang akan mengisi adalah ketua tim dan diperiksa oleh dosen pengajar dan staf yang ditunjuk oleh unit kerja atau perusahaan di mana tim audit melakukan audit kepatuhan. Evaluasi yang kedua didasarkan pada bundel pelaporan dan presentasi hasil audit kepatuhan.
4.5.1. Evaluasi Kinerja Proses Audit Kepatuhan (60\%)

Adapun komponen untuk evaluasi kinerja proses audit kepatuhan adalah sebagai berikut:

a. Tahap Persiapan oleh Tim Audit $(10 \%)$

b. Tahap Pelaksanaan oleh Tim Audit $(20 \%)$

c. Tahap Pelaporan oleh Tim Audit $(30 \%)$

Evaluasi terhadap proses audit kepatuhan ini menitiberatkan pada kegiatan persiapan, pelaksanaan, dan pelaporan dari tim audit untuk melihat fisikal motorik dari mahasiswa.

4.5.2. Evaluasi Kinerja Hasil Audit Kepatuhan (40\%)

Adapun komponen untuk evaluasi kinerja hasil audit kepatuhan adalah sebagai berikut:

a. Kertas Kerja Hasil Pengisian Daftar Pertanyaan (10\%)

b. Kertas Kerja Hasil Pengujian Audit Kepatuhan (10\%)

c. Slide Presentasi (10\%)

d. Video Presentasi (10\%)

Evaluasi terhadap kinerja hasil audit kepatuhan ini menitikberatkan pada output dari kegiatan tim di mana dalam audit kepatuhan, tim audit harus mampu menyusun semua kertas kerja yang hasilkan. Sedangkan slide dan video presentasi merupakan bukti pendukung bahwa kegiatan saja.

\section{KESIMPULAN DAN SARAN}

\subsection{Kesimpulan}

Adapun kesimpulan dari penelitian ini adalah untuk mendapatkan suatu model pembelajaran melalui project-based learning untuk materi kuliah audit kepatuhan pada mata kuliah auditing. Berikut ini adalah model pembelajaran project-based learning audit kepatuhan: 


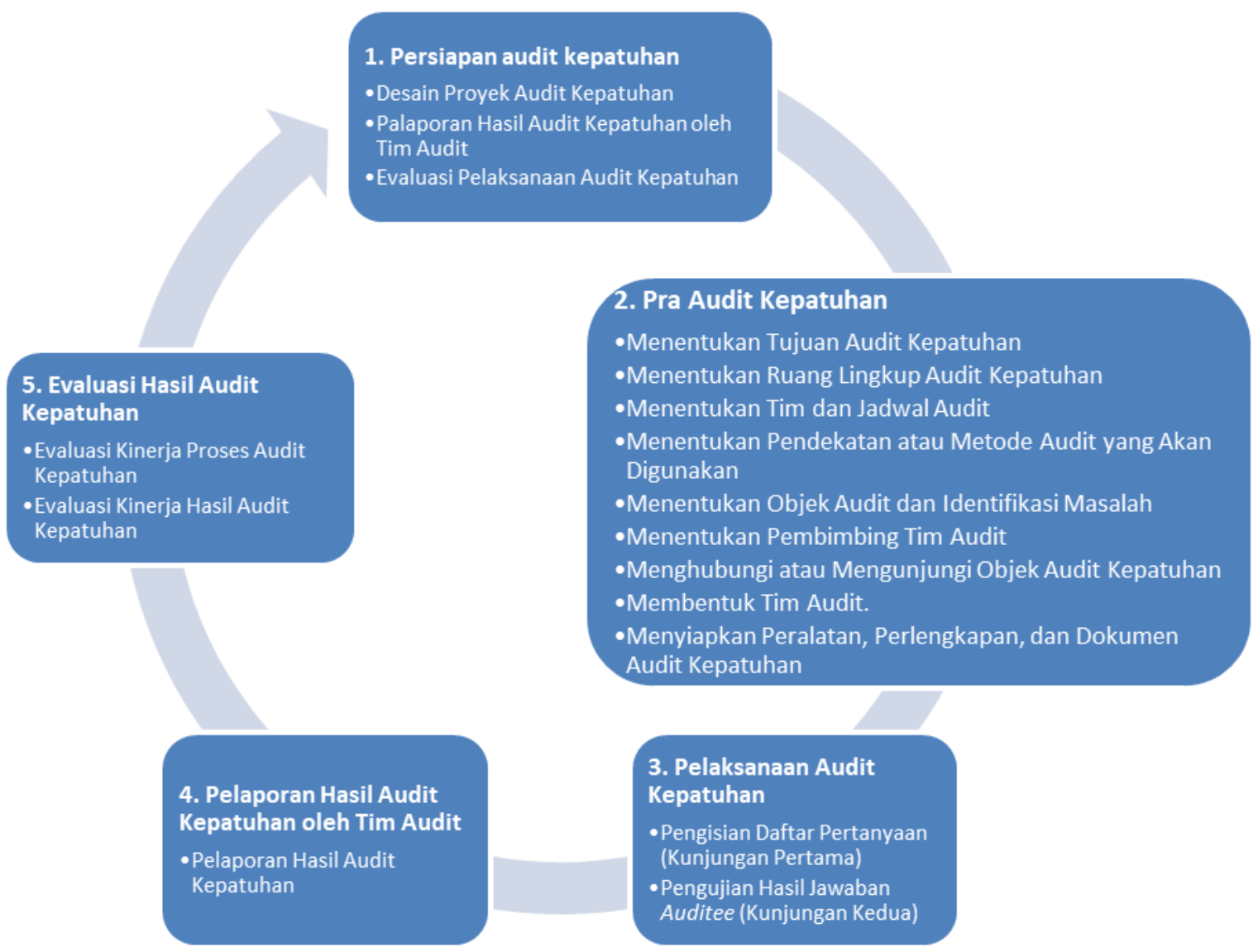

Gambar 1. Model Pembelajaran Project-Based Learning

\subsection{Saran}

Adapun saran-saran dari hasil penelitian ini adalah sebagai berikut:

1. Menentukan desain proyek PBL harus direncakanan secara matang dan terstruktur.

2. Penentuan auditee memerlukan waktu yang cukup lama, sebaiknya terjalin komunikasi antara dosen, pembimbing, dan ketua tim audit.

3. Dosen dan pembimbing harus lebih cermat dalam me-review hasil pengujian, terutama dokumen pendukungnya.

4. Proses pelaporan oleh tim audit harus pemantauan yang intensif dari pembimbing.

5. Seluruh hasil evaluasi harus didukung bukti sebagai bentuk pertanggung jawaban tim dari hasil PBL.

\section{DAFTAR PUSTAKA}

Afriana, J. (2015). Project Based Learning. Bandung: Pendidikan IPA Sekolah Pascasarjana UPI.

Agoes, S. (2012). Auditing: Petunjuk Praktis Pemeriksaan Akuntan oleh Akuntan Publik. Jakarta: Salemba Empat.

Agoes, S. (2017). Auditing: Petunjuk Praktis pemeriksaan Akuntan oleh Akuntan Publik (5 ed.). Jakarta: Salemba 4.

Arens, A. A., Elder, J. R., \& Beasley, S. M. (2015). Auditing an Assurance Service. Pretince Hall.

Gangga, A. (2013). Penerapan Model Pembelajaran Project Based Learning dalam Peningkatan Motivasi dan Hasil Belajar. Padang: Universitas Negeri Padang.

Hamdayama, J. (2015). Model dan Metode Pembelajaran kreatif dan 
Berkarakter. Bogor: Ghalia Indonesia.

Hare, A. P. (1962). Handbook of Small Group Research. New York and London: Collier-McMillan Limited.

Herawan, H. E., \& Rahayu, L. (2016). Pengaruh Aktivitas Belajar Siswa dalam Penerapan Model Project Based Learning Berbasis Saintifik Terhadap Hasil Belajar pada Mata Pelajaran Akuntansi. EDUNOMIC JURNAL PENDIDIKAN EKONOMI.

Moursund, D. (2003). Project-Based Learning Using Information Technology (2 ed.). Eugene: International Society for Technology in Education.

Mukhayyaroh, I. A., \& Arief, S. (2018). Penerapan Project Based Learning Untuk Meningkatkan Kreativitas, Motivasi Belajar dan Hasil Belajar. Economic Education Analysis Journal.

Mulyadi. (2014). Auditing (6 ed.). Jakarta: Salemba Empat.

Nurfitriyanti, M. (2016). Model Pembelajaran Project Based Learning Terhadap Kemampuan Pemecahan Masalah Matematika. Jurnal Ilmiah Pendidikan MIPA.

Santyasa, I. W. (2006). Pembelajaran Inovatif: Model Kolaboratif, Basis Proyek dan orientasi NOS. Makalah. Semapura: Universitas Pendidikan Ganesha.

Sharan, Y., \& Sharan, S. (1992). Group Investigation: Expanding Cooperative Learning. Nueva York: Teacher's College Press.

Sukmadinata, N. S. (2011). Metode Penelitian Pendidikan. Bandung: Remaja Rosdakarya.

Trianto. (2011). Model Pembelajaran Terpadu konsep, Strategi dan implementasinya dalam Kurikulum Tingkat Satuan Pendidikan (KTSP), Jakarta: Bumi Aksara. Jakarta: Bumi Aksara. 